\title{
O Tema Gerador na Formação de Pedagogas do Alto Sertão Alagoano: da Escuta Sensível ao Planejamento de Ciências
}

\author{
Generative Themes in Teaching Training Courses in Brazilian Sertão: from \\ Sensitive Listening to Science Planning
}

Ana Paula Solino, ${ }^{(10)}$ Polliane Santos de Sousa, Roger Magalhães da Silva, ${ }^{(1)}$ Simoni Tormöhlen Gehlen

Palavras-chave Resumo Investigam-se desafios e potencialidades na elaboração Formação Inicial de de planejamentos didático-pedagógicos da Educação em Ciências,

Professores; com base na Abordagem Temática Freireana. Metodologicamente, Paulo Freire; o trabalho foi realizado na disciplina de Planejamento, Currículo e Educação em Avaliação, envolvendo oito licenciandas do $5^{\circ}$ período do curso de Ciências. Pedagogia da UFAL. Obteve-se as informações a partir de diários, portfólios e grupo focal, durante a vivência das licenciandas nas etapas da Investigação Temática, as quais foram analisadas por meio da Análise Textual Discursiva e organizadas em três categorias: i) Conhecendo a comunidade local; ii) Análise das informações e seleção do Tema Gerador e iii) Seleção do conteúdo programático e elaboração de planos de aulas de Ciências. Dentre os resultados, destacam-se: o protagonismo das licenciandas durante o planejamento de aulas de ciências sob a atuação crítico-analítica e criativa; a compreensão sobre a importância da escuta do Outro como pressuposto fundamental para a obtenção de Temas Geradores; a definição de parâmetros para identificar e analisar falas significativas da comunidade escolar. Chama-se atenção para a importância de aprofundar esses parâmetros, pois podem contribuir na elaboração de perguntas problematizadoras. Ademais, inserções da Investigação Temática no curso de Pedagogia podem potencializar processos formativos coerentes com a proposta ético-crítico da educação libertadora, a partir do exercício da escuta sensível do Outro. 
Keywords Abstract This paper investigates challenges and potentialities of Preservice Teacher planning teaching strategies in Science Education, based on Freire's

Education; Thematic Approach. Methodologically, the research was conducted Paulo Freire; during a course in Planning, Curriculum and Assessment, involving Science eight undergraduates from the 5th term of the Education Program Education. at UFAL. The information was obtained from diaries, portfolios and a focus group during the stages of Thematic Investigation, which were analyzed using Discursive Textual Analysis, and put into three categories: i) Getting to know the local community; ii) Analysis of information and selection of the Generative Theme, and; iii) Selection of syllabus and preparation of science teaching strategies. The following results stood out: the active role of the undergraduates during the planning of science classes under critical-analytical and creative performance; the understanding that listening to the Other is fundamental for obtaining Generative Themes; the definition of parameters to identify and analyze relevant speeches from the school community. Particular attention is drawn to the importance of deepening these parameters, which can contribute to the elaboration of problem-posing questions. Introducing Thematic Investigation in Education courses can enhance formative processes based on the ethical-critical commitment of a liberating education, from the exercise of sensitive listening.

\section{Introdução}

Discussões relacionadas à reconfiguração de currículos escolares, em diversos contextos e níveis de ensino, têm sido foco de alguns estudos na área de Educação em Ciências. Por exemplo, aqueles que têm como objeto de estudo a estruturação de programas curriculares com base em problemas que envolvem contradições sociais da comunidade escolar, isto é, Temas Geradores obtidos mediante o processo de Investigação Temática (IT) (Mendonça, 2016; Saul, 2016; Silva, 2004; Stuani, 2016). Pautados na concepção freireana de educação, tais estudos apresentam uma dimensão ético-crítica em que a realidade concreta, tomada enquanto objeto de estudo, é problematizada e apreendida em sua totalidade sociocultural, almejando o desvelamento de situações reais que constituem obstáculos para a realização plena dos sujeitos (Delizoicov et al., 2020).

De acordo com Delizoicov et al. (2020), a análise desses processos evidencia que a investigação das condições de vida da comunidade realizada para a construção da programação escolar proporciona um processo praxiológico de formação permanente dos/as educadores/as, contribuindo com o distanciamento e a problematização da rotina escolar e o enfrentamento reflexivo dos limites e das possibilidades das práticas pedagógicas. Para os autores, iniciativas desenvolvidas, ainda que pontualmente em cursos de licenciaturas, precisam se tornar objetos de pesquisa, pois podem contribuir 
com a implementação de propostas ético-críticas tanto por educadores/as que atuam na educação básica quanto por docentes formadores e licenciandos/as em cursos de formação inicial.

Destarte, alguns estudos têm incorporado aspectos do processo de Investigação Temática na formação inicial de professores/as em diversos contextos e áreas de conhecimento, como em cursos de: Licenciatura em Física (Sousa et al., 2015; Muenchen et al., 2019), Licenciatura em Biologia (Demartini \& Silva, 2013; Jesus et al., 2021), Licenciatura em Química (Silveira et al., 2020), Licenciatura em Educação do Campo (Moreno, 2020) e no Programa Institucional de Bolsas de Iniciação à Docência (PIBID) (Auler \& Auler, N., 2015; Paniz, 2017). Segundo Roso et al. (2015), promover vivências desta natureza aos estudantes em formação inicial possibilita a discussão de categorias importantes, a exemplo dos conceitos de interdisciplinaridade e cotidiano e da diferença entre configuração curricular e metodologia. Silveira et al., (2020) também destacam, a partir da análise da apropriação dessa perspectiva por licenciandos do curso de Licenciatura em Química da Universidade Federal de Santa Catarina, que o trabalho pautado na Abordagem Temática Freireana (ATF) favorece a pesquisa sobre a prática docente e seus fundamentos.

Também é preciso discutir essas questões relacionadas à reconfiguração curricular no contexto dos Anos Iniciais, assim como há a necessidade de inserir, neste nível de ensino, atividades que contemplem aspectos da ciência e tecnologia voltadas à formação de sujeitos críticos e participativos na sociedade (Solino, 2013). Os cursos de Pedagogia são espaços de formação que necessitam abordar essas questões, em especial nas disciplinas que abordam o Ensino de Ciências, uma vez que essa área é pouco aprofundada nesses cursos e pouco valorizada nos currículos escolares dos Anos Iniciais (Ovigli \& Bertcci, 2009; Pires \& Malacarne, 2018). Além disso, Pires e Malacarne (2018) destacam que nos cursos de formação de pedagogos são raras as propostas curriculares que estejam comprometidas com uma visão de Ciência que contemple questões sociais e políticas. Por esta razão, faz-se necessário formar futuras/os pedagogas/os que compreendam as relações entre a Ciência e a Sociedade, valorizando a formação de cidadãos críticos perante o mundo em que vivem.

Sob esse prisma, algumas iniciativas estão sendo realizadas por grupos de pesquisas, a exemplo do Grupo de Estudos e Pesquisa sobre Abordagem Temática no Ensino de Ciências (GEATEC), vinculado à Universidade Estadual de Santa Cruz (UESC), e, mais recentemente, pelo Grupo de Estudos e Pesquisa sobre Abordagem Freireana em Ambientes Escolares (GEAFAE), vinculado à Universidade Federal de Alagoas, campus do Sertão, os quais têm buscado atuar na formação inicial e continuada de professores/as de Ciências e de Pedagogia em municípios do interior do nordeste brasileiro. Tais grupos vêm trabalhando de maneira articulada buscando desenvolver processos formativos tendo como referência a ATF (Delizoicov et al., 2011) e a Práxis Organizativa Curricular via Tema Gerador (PCTG) (Silva, 2004).

Parte-se do pressuposto de que as discussões realizadas sobre a formação inicial de 
professores/as, em especial de Pedagogas/os, tendo como aporte as ideias de Paulo Freire podem potencializar a elaboração e planejamento de atividades didático-pedagógicas contextualizadas e pautadas nas condições materiais das comunidades escolares da região sertaneja do estado de Alagoas. Isto, porque há um grande número de alunos/as que frequentam as escolas públicas dessa região que são oriundos de famílias carentes, que vivenciam diversos problemas sociais referentes às questões da seca, desigualdade, pobreza, desemprego, violência doméstica, entre outros. Tais problemas refletem as condições precárias de vida desses sujeitos e precisam ser constantemente refletidas e transformadas (Freire, 1987).

Sendo assim, busca-se neste estudo responder a seguinte questão de pesquisa: Como licenciandas do curso de pedagogia se apropriam da proposta educacional freireana a partir do planejamento de atividades didático-pedagógicas de Ciências? Com o propósito de responder a essa questão, essa pesquisa investiga desafios e potencialidades na elaboração de planejamentos didático-pedagógicos da Educação em Ciências, com base na Abordagem Temática Freireana, com um grupo de licenciandas em Pedagogia da Universidade Federal de Alagoas, Campus do Sertão.

\section{A escuta sensível no Tema Gerador e a formação inicial de professores/as}

O estudo de Delizoicov (1982) é um dos primeiros a sistematizar a possibilidade de inserir aspectos relacionados ao processo de obtenção de Temas Geradores no contexto escolar. Inspirado neste estudo, há mais de quatro décadas o processo de Investigação Temática tem sido objeto de pesquisas da Educação em Ciências, as quais têm se debruçado, em especial, sobre a reorganização curricular e a formação permanente de professores/as. Delizoicov et al., (2020) explicitam diversos trabalhos implementados em redes públicas de ensino que adotaram pressupostos freireanos para a construção de currículos escolares. Apesar das especificidades envolvidas em tais trabalhos e em função das particularidades locais e da organicidade da Investigação Temática, destacam-se como orientadores do processo de construção curricular as sistematizações propostas pela ATF (Delizoicov et al., 2011) e pela Práxis Organizativa Curricular via Tema Gerador (Silva, 2004).

A ATF tem sido utilizada por diferentes estudos como alicerce para a construção de programas escolares. Sob esse prisma, o processo de obtenção de Temas Geradores pode ser compreendido em cinco etapas, sintetizadas por Delizoicov et al., (2011) como seguem: i) Levantamento Preliminar: consiste na busca por informações acerca das condições de vida da comunidade escolar, mediante pesquisa em fontes secundárias e conversas informais com a comunidade local; ii) Análise das situações e escolha das codificações: envolve a análise das informações obtidas na etapa anterior a partir da qual serão selecionadas e codificadas situações representativas de contradições sociais vivenciadas; iii) Diálogos descodificadores: discussão das codificações elaboradas com representantes da comunidade e obtenção do Tema Gerador; iv) Redução temática: 
elaboração do programa escolar a partir dos resultados das etapas anteriores, em que são utilizados os Três Momentos Pedagógicos ${ }^{1}$ (Delizoicov et al., 2011) para o planejamento das atividades de sala de aula; v) Trabalho em sala de aula: desenvolvimento das atividades didático-pedagógicas planejadas.

Resultado do aprofundamento do processo de Investigação Temática proposto pela ATF e mediante o desenvolvimento e análise das ações de reconfiguração curricular em diversos municípios do Brasil fundamentados na perspectiva educacional de Paulo Freire, a Práxis Organizativa Curricular via Tema Gerador (Silva, 2004) evidencia outras dimensões da construção de currículos ético-críticos. Em especial, ela presta particular atenção à formação permanente dos/as educadores/as e à escuta dos sujeitos que compõem o contexto escolar na elaboração das programações curriculares. Seus momentos organizacionais podem ser descritos, em síntese, como: i) Momento I Desvelamento do real pedagógico a partir das necessidades imanentes da prática: envolve a reflexão sobre a prática pedagógica vigente na escola, identificando e problematizando situações reconhecidas pelos sujeitos como limítrofes, a partir das quais se vislumbram outras possibilidades; ii) Momento II - Resgate das falas significativas constituindo sentido à prática (elegendo temas/contratemas): consiste em uma pesquisa sociocultural sobre a comunidade escolar a partir da qual se pretende identificar falas significativas, isto é, situações-limite, que serão problematizadas junto a representantes locais na busca dos Temas Geradores e seus reversos, denominados Contratemas; iii) Momento III Contextualização e percurso do diálogo entre falas e concepções da realidade local (Rede Temática e questões geradoras): há a construção de uma Rede Temática, instrumento analítico-propositivo que sintetiza as diferentes visões da realidade investigada, a partir da qual serão elaboradas as questões geradoras gerais da proposta; iv) Momento IV - Planejamento e organização pedagógica da prática crítica: elaboração do programa escolar a partir de questões geradoras específicas por área do conhecimento, as quais orientam a seleção do conteúdo programático e a implementação da proposta; v) Momento V - Reorganização coletiva da escola a partir do fazer pedagógico: momento de reflexão docente sobre o processo de construção e implementação vivenciado.

Vale frisar a ênfase atribuída pela Práxis Organizativa Curricular via Tema Gerador ao processo de escuta do Outro, representada, em particular, pela identificação de falas significativas durante a Investigação Temática. De acordo com Silva (2004), as falas significativas constituem "[...] falas dos diferentes segmentos escolares que trazem a denúncia de algum conflito ou contradição vivenciados pela comunidade local e que expressam uma determinada concepção, uma representação do real" (p. 56). Tais falas estabelecem o ponto de partida do planejamento educacional, materializando o pensar

1 São eles: i) Problematização Inicial: apresentação e discussão de situações vinculadas ao Tema Gerador para que os/as educandos/as compartilhem suas explicações sobre os fenômenos, as quais serão problematizadas de tal modo que sintam a necessidade de aquisição de novos conhecimentos; ii) Organização do Conhecimento: abordagem dos conhecimentos científicos necessários para aprofundar a compreensão acerca das situaçõesproblema apresentadas anteriormente; iii) Aplicação do Conhecimento: resgate das situações abordadas na problematização inicial para uma nova análise, mediante os novos conhecimentos apreendidos, e abordagem de outras situações regidas pelos mesmos princípios. 
do povo acerca das suas condições de vida, representando o seu pensamento-linguagem referido à realidade, ou seja, sua visão de mundo (Freire, 1987). Quando aliadas às demais informações obtidas na pesquisa sociocultural sobre a comunidade escolar (registros fotográficos, dados estatísticos, etc.) essas falas evidenciam o binômio objetividadesubjetividade presente no Tema Gerador. Assim, constituindo o ponto de partida da realidade concreta, tais falas serão problematizadas em suas diferentes dimensões para que, a partir de uma visão relacional, sejam contextualizadas e evidenciadas suas contradições, identificando não apenas o Tema Gerador - considerado como denúncia de uma determinada situação-limite vivenciada -, mas também o seu contrário, o Contratema - considerado anúncio de uma nova forma de perceber e agir sobre o problema, isto é, o ponto de chegada do processo educativo a partir do qual é possível vislumbrar outras condições de vida.

Essas discussões entre anúncio e denúncia dos problemas vivenciados pelos sujeitos são sistematizadas em forma de rede, denominada por Silva (2004) como Rede Temática, que pode ser considerada como um instrumento analítico que sintetiza a multiplicidade de sentidos atribuídos pelos sujeitos que estão envolvidos no processo de análise da realidade local, isto é, os sujeitos da comunidade local, da comunidade escolar e a equipe de pesquisadores. O contraste entre as visões desses atores possibilita que os/as educadores/as façam uma leitura crítica sobre as falas significativas presentes na rede, de modo a identificar as situações-limite, seus Temas e Contratemas. A proposta da Rede Temática formulada por Silva (2004) teve como referência a Ética da Libertação de Enrique Dussel, a qual compreende que é a partir das negatividades que um projeto educacional preocupado com a emancipação dos sujeitos deve partir para se chegar a práticas contextualizadas. Para Silva (2004):

Partir do discurso concreto dos sujeitos, das falas significativas das vítimas é, sem dúvida, a primeira exigência de um projeto educacional comprometido com a democratização, pois a fala do excluído representa o ataque mais radical à pretensão de totalidade que o sistema instituído pode sofrer (p. 129).

Para a identificação de tais falas, Silva (2004) ainda sinaliza que estas podem ser caracterizadas a partir:

a) da capacidade de inter-relacionar dados, informações e principalmente visões e percepções de mundo, configurando individualmente ou em termos coletivos a realidade analisada; b) do fato de representarem e compreenderem contradições sociais da micro ou da macro organização social e de estarem implícitas ou explícitas na fala a partir da análise de seus múltiplos significados; c) da possibilidade de serem analisadas pelas diferentes disciplinas, permitindo a seleção de conhecimentos que viabilizem uma leitura crítica da realidade local e de mundo; d) da frequência em que aparecem e são abordadas pela comunidade ou, como contraponto, quando são enfaticamente negadas demonstrando recusas deliberadas e passionais; e) da pertinência e relevância para a comunidade escolar 
em especial (p. 202).

O que se busca nessas falas significativas é a compreensão dos sujeitos sobre a realidade em que vivem, mas não é qualquer realidade, mas sim aquela que representa contradições sociais, que necessitam ser compreendidas e superadas. São as falas significativas que passam a representar o Tema Gerador, como explicam Demartini e Silva (2013):

Cada fala expressa uma ou mais contradições, limites explicativos em torno dos quais identificamos visões de mundo, dúvidas, angústias que devem fazer parte da programação curricular. A depender do tipo de contradição expressa, essas falas podem ser classificadas, mas uma em especial é importante, pois, é uma contradição maior que se caracteriza no "Tema Gerador", a partir do qual e junto com outras contradições menores, comporá e norteará a construção da programação curricular (Demartini \& Silva, 2013, p. 6).

Destaca-se que as etapas da identificação de Temas Geradores não podem ser compreendidas como estanques, porque constituem um processo dialético de investigação da realidade (Silva, 2004; Sousa, 2014). Por essa razão, algumas modificações da Investigação Temática têm sido realizadas almejando incorporar um olhar ético-crítico ao planejamento escolar (Centa \& Muenchen, 2018; Demartini \& Silva, 2013; Furlan et al., 2011; Jesus et al., 2021; Lambach, 2013; Milli et al., 2018; Stuani, 2016). Isto é, as etapas apresentadas para a obtenção de Temas Geradores são direcionamentos para que características fundamentais da perspectiva freireana possam ser contempladas no processo de ensino-aprendizagem. Contudo, há aspectos que necessitam ser considerados de forma mais sistemática, como a valorização do ouvir o Outro. Assim, ainda que diversos estudos discutam elementos relacionados ao processo de Investigação Temática na formação inicial de professores/as em variados contextos e áreas de conhecimento, suas condições materiais de realização nem sempre possibilitam momentos efetivos de escuta da comunidade local e escolar.

Entre as iniciativas preocupadas com essa dimensão do planejamento curricular na perspectiva freireana, há estudos que têm priorizado de forma sistemática a escuta do Outro na obtenção de Temas Geradores nos cursos de licenciaturas. Dentre eles, os trabalhos de Jesus et al. (2021) e Demartini e Silva (2013), desenvolvidos no contexto do PIBID com licenciandos em Ciências Biológicas da Universidade Federal de São Carlos (UFSCar, campus Sorocaba/SP). O que chama a atenção nesses estudos é o processo de obtenção e análise das falas significativas, que sinaliza uma preocupação com o Outro, revelando o rigor na seleção e legitimação das contradições sociais e limites explicativos que representam o Tema Gerador. Isso porque a escuta do Outro e a análise de seus modos de compreensão da realidade direcionam-se à exigência, sinalizada por Brick (2017), "de que o próprio processo de investigação seja visto como uma situação gnosiológica, como um processo educativo humanizador” (p. 170), pressuposto essencial para que a abordagem de Temas Geradores não se reduza ao estruturalismo de uma prática educativa pautada numa sequência de meras etapas instrumentais. 
No estudo de Jesus el al. (2021), por exemplo, o Tema Gerador é selecionado por meio das etapas da Investigação Temática, inspiradas na proposição de Silva (2004), realizadas com estudantes do Ensino Fundamental II e Ensino Médio. Para obter possíveis situações significativas oriundas da comunidade escolar, que podem ser representadas nas falas dos alunos/as, os autores relatam que foram realizadas questões como:

$\mathrm{O}$ que te deixa feliz?, O que te deixa triste?, O que você gosta e o que não gosta a respeito do bairro em que mora? Por quê?, Como você se imagina no futuro?, $\mathrm{O}$ que você gosta e o que você não gosta de fazer no seu dia a dia? Por quê? (Jesus et al., 2021, p. 4).

Nas respostas a essas questões foram analisadas as visões de mundo dos/as estudantes e identificadas hipóteses de contradições sociais que expressam limites explicativos em torno das situações significativas por eles vividas, compartilhados por parte expressiva de cada turma. Com isso, os autores identificaram algumas tendências no conjunto das falas, como violência doméstica, conflitos relacionados à temática de gênero e falta de opções de lazer. E para cada uma dessas falas significativas apresentadas pelos/as alunos/as, os autores realizaram uma análise tendo como parâmetro: os limites explicativos dos/as estudantes, os elementos estruturantes dessas falas, as visões de mundo dos/as educadores/as em torno das mesmas e os respectivos elementos estruturantes presentes na visão dos/as educadores/as. Dessa análise e seleção resultou na identificação do Tema Gerador.

Esse processo é fulcral na construção de programas escolares na perspectiva freireana, sob o prisma ético-crítico, e possui o potencial para contribuir com a construção de um novo olhar dos/as licenciandos/as envolvidos/as na constituição do currículo escolar, da própria finalidade da educação numa perspectiva ético-crítica e do papel do/a educador/a nesse processo. Por isso, também, é importante realizar esse movimento de escuta com os/as licenciandos/as envolvidos/as em atividades dessa natureza, tendo em vista identificar os conhecimentos por eles construídos, a fim de possibilitar a organização de futuras práticas docentes.

\section{Procedimentos Metodológicos}

A pesquisa ${ }^{2}$ foi desenvolvida na Universidade Federal de Alagoas (UFAL, Campus do Sertão), situada na região do nordeste brasileiro, no estado de Alagoas. Esse estado apresenta baixos índices socioeconômicos e educacionais, representando um descompasso significativo em relação a outros estados do país, porque expõe a desigualdade e a pobreza na região. Essa situação ainda é mais preocupante quando se observa a realidade sertaneja, devido ao lamentável problema da seca. É nesse contexto que a UFAL/Sertão se insere e, por isso mesmo, vem contribuindo com o desenvolvimento

2 Este trabalho faz parte de um conjunto de atividades relacionadas ao projeto de pesquisa intitulado: “Contribuições de Paulo Freire para a Educação em Ciências na Bahia e Alagoas”, Chamada MCTIC/CNPq No 28/2018, Processo: 423942/2018-2, aprovado pelo Comitê de Ética em Pesquisas com Seres Humanos: CAAE: 30004620.6.3002.5013. 
da região articulando, sobretudo, no curso de Pedagogia, a necessária valorização local por meio da contextualização dos conhecimentos científicos na formação docente (UFAL, 2018).

O estudo teve como contexto a disciplina ${ }^{3}$ de Planejamento, Currículo e Avaliação (PCA) do curso de Pedagogia, com carga horária total de 80 (oitenta horas). O período de abrangência dessa experiência ocorreu no segundo semestre letivo de 2018 com licenciandas do $5^{\circ}$ período do curso de Pedagogia. A turma era composta por 27 licenciandas e 1 licenciando e ministrada pela primeira autora deste estudo. A disciplina foi organizada em duas partes, contemplando os seguintes aspectos: 1) Discussões sobre o planejamento da prática docente; dimensões epistemológicas e pedagógicas do planejamento curricular; construção de planos de aulas; desafios e perspectivas da avaliação; 2) Análises sobre o papel da realidade sociocultural dos alunos/as nos planejamentos didático-pedagógicos. A partir de então, a proposta freireana de educação foi trabalhada, com o intuito de proporcionar vivências aos licenciandos/as sobre a construção de planejamentos curriculares críticos e participativos, tendo como ponto de partida a realidade concreta dos/as alunos/as da escola, com vistas a construir uma educação democrática, contextualizada e transformadora.

O foco de discussão deste estudo concentrar-se-á na segunda parte trabalhada na disciplina, que foi organizada em 8 aulas distribuídas entre os meses de janeiro a março de 2019. Para investigar a compreensão dos/as licenciandos/as envolvidos/as no processo de elaboração dos planejamentos didático-pedagógicos com base na ATF, foram utilizados três instrumentos de obtenção de informações: diários, portfólios e grupo focal. Os diários foram construídos pelos/as licenciados/as durante o semestre letivo para o registro das atividades realizadas na disciplina. Os portfólios foram elaborados pelos/as discentes e neles constam seus relatos de experiências e descrição de aspectos relacionados ao processo de Investigação Temática, um programa curricular e planos de aulas tendo como referência diferentes áreas de conhecimento, ou seja, uma síntese de todas as atividades realizadas na disciplina de PCA. Foram analisados apenas 4 (quatro) portfólios, tendo como critério aqueles que apresentaram um plano de aula relacionado ao Ensino de Ciências.

Destaca-se que os portfólios foram elaborados sob o prisma das narrativas (Cunha, 1997), e na análise destes, identificou-se a necessidade de investigar algumas compreensões das licenciandas sobre a construção dos planos de aula, voltados para a área de Ensino de Ciências. Para isso, foram convidadas quatro duplas de licenciandas para participarem do grupo focal ${ }^{4}$ (Gatti, 2005), totalizando oito discentes. A escolha por essas licenciandas se deu também pelo fato delas apresentarem uma vivência em comum com o processo de Investigação Temática, durante a disciplina de PCA, o que

3 A escolha da disciplina justifica-se pelo fato dela favorecer a abordagem de conteúdos sobre o planejamento e o currículo escolar. A Autora 1, na ocasião, foi responsável pela disciplina no momento de realização da pesquisa. $4 \mathrm{O}$ grupo focal foi realizado dois anos após as atividades da disciplina, isto é, no primeiro semestre de 2021. Essa técnica ocorreu de forma on-line, tendo em vista a interrupção de aulas presenciais nas universidades públicas, devido a pandemia causada pela novo Coronavírus. 
permitiu apresentarem elementos importantes sobre a compreensão dessa perspectiva, sob o olhar do Ensino de Ciências. Algumas questões foram apresentadas às licenciandas para orientar/conduzir as discussões do grupo focal, quais sejam:

Figura 1. Questões orientadoras do grupo focal

1) Ao terem contato novamente com o portfólio, vocês observam que tiveram que construir três planos de aulas, certo? Alguém aqui gostaria de comentar como foi esse processo?

2) Diante da diversidade de conteúdos que foram selecionados, por que vocês optaram em fazer um Plano de Aula para o Ensino de Ciências?

3) A forma como vocês organizaram o plano de aula contempla alguns pressupostos de Paulo Freire? Vocês lembram de algum? Qual?

4) De que forma o Ensino de Ciências pode contribuir para ajudar os/as alunos/as a terem um novo olhar sobre os problemas vivenciados no bairro e no mundo?

5) Vocês se recordam se tiveram dificuldades para elaborar esse Plano de Aula de Ciências? Se sim, poderiam comentar um pouco?

6) Se vocês tivessem a oportunidade de refazer esse plano de aula de ciências, o que vocês mudariam? Fonte: Elaborado pelo/as autor/as.

A análise das informações obtidas a partir dos diários, portfólios e do grupo focal foi realizada por meio da Análise Textual Discursiva (ATD) (Moraes \& Galiazzi, 2011) - que compreende a unitarização, categorização e metatexto - tendo como referência as etapas do processo de Investigação Temática. Assim, as informações do diário e do portfólio e as falas obtidas do grupo focal constituíram as unidades de significado; as categorias foram estabelecidas a priori, tendo em vista o objetivo da pesquisa de investigar a apropriação das licenciandas acerca do processo de elaboração de atividades didáticopedagógicas de ciências com base nas etapas da ATF; e o metatexto compreendeu a interpretação dessas falas. Destaca-se que a ATD se configura como "uma bússola praxiológica da Investigação Temática, a qual aponta o caminho à práxis, seja no reconhecimento ou na produção de novos conhecimentos necessários à transformação da realidade" (Milli et al., 2020, p. 762). Ou seja, a ATD é uma ferramenta aberta à realização da práxis, contribuindo para uma análise efetiva do processo de Investigação Temática.

Nesse contexto, foram delineadas as seguintes categorias baseadas na Investigação Temática: i) Conhecendo a comunidade local: apresenta as informações obtidas pelas licenciandas sobre a comunidade escolar e a concepção dos moradores locais sobre a realidade em que vivem; ii) Análise das informações e seleção do Tema Gerador: tem como objetivo explicitar de que forma foi realizada a análise das informações do reconhecimento da realidade e como foi selecionado o Tema Gerador; e iii) Seleção do conteúdo programático e elaboração de planos de aulas de Ciências: tem como foco a organização que as licenciandas fizeram das atividades relacionadas à seleção de conteúdos e conceitos científicos necessários para entender e superar o Tema Gerador. A seguir são apresentadas as discussões realizadas em cada categoria (metatexto), nas 
quais a identificação das oito licenciandas que participaram da pesquisa é realizada por meio de nomes fictícios ${ }^{5}$ preservando-se a identidade destas. Ademais, nos excertos extraídos dos diários construídos pelas discentes durante o estudo da realidade local, foi utilizado o sistema alfanumérico Morador 1, Morador 2, ..., Morador n, Comerciante 1, Comerciante $2, \ldots$ resguardando-se, também, suas identidades.

\section{A Investigação Temática e a compreensão das licenciandas do curso de Pedagogia}

\section{i) Conhecendo a comunidade local}

Essa primeira etapa, na organização proposta por Delizoicov (1982; 1991), tem como finalidade identificar aspectos que caracterizam a comunidade local, bem como a compreensão dos sujeitos sobre ela. Nesse sentido, no presente estudo foi realizada uma observação do entorno da escola e a busca dos principais aspectos que pudessem configurar situações-limite vivenciadas pela comunidade.

$\mathrm{O}$ estudo foi realizado em um dos bairros próximos à universidade, onde fica situada uma escola municipal do Ensino Fundamental. O bairro é bastante movimentado por estar perto a uma rodovia estadual, porém afastado do centro da cidade. Assim, é considerado um bairro periférico, cuja população é de baixa renda. A escola, por sua vez, atende boa parte dos/as alunos/as residentes no bairro e adjacências, ofertando vários segmentos da educação básica, tais como a educação infantil e ensino fundamental anos iniciais e finais, com aproximadamente 400 estudantes.

Nesse primeiro momento, as licenciandas fizeram a visita ao bairro e observaram os principais problemas vivenciados pelos sujeitos que lá residiam ou trabalhavam, a partir de fotografias do local e conversas informais com funcionários da escola, moradores, comerciantes e lideranças do bairro, as quais foram registradas nos seus diários. Também foram realizadas pesquisas nos principais blogs e sites jornalísticos da região para conhecer um pouco mais sobre as situações cotidianas daquela localidade.

Quando as licenciandas questionaram a comunidade local se gostava do bairro e o que achava sobre ele, alguns moradores responderam:

Sim, gosto. O bairro é bom. Moro aqui há muito tempo e já melhorou muita coisa (Fala do morador 1 - extraída do diário).

“Ome”, aqui não é bom é de jeito nenhum [risos]. Eu mesmo não gosto de nada aqui. Assim, só é bom porque todo mundo é conhecido, é amigo, aí é bom, mas fora isso [...] óh a rua aí como tá, toda cheia de buraco [...] os moradores que têm que ajeitar e tapar os buracos. Esse quebra-mola aí mesmo foi o povo aí da

5 Os nomes fictícios atribuídos às licenciandas foram escolhidos com o intuito de homenagear algumas cientistas brasileiras que produziram pesquisas e/ou desenvolveram trabalhos importantes para o enfrentamento da pandemia provocada pelo novo coronavírus SARS-CoV-2, dentre elas: Nísia Verônica Trindade Lima, Margareth Dalcomo, Natália Pasternak, Jaqueline Goes de Jesus e Ester Cerdeira Sabino. 
rua que fez. Ali na rua de cima, tinha um buraco, o povo que teve que ajeitar. Aqui é assim, é poste sem luz, é rua com buraco [risos]. Na rua que eu moro, ali em cima, o poste tava sem luz, o dono da chácara que colocou. Ligaram pra prefeitura, mas ninguém ajeitava, aí ele foi, comprou a lâmpada e botou; e ainda é azul a luz lá que ele botou [risos]. (Fala do morador 15 - extraída do diário).

Não. Não mudaria nada [no bairro]. Não posso colocar falta onde não tem, né? (Fala do morador 4 - extraída do diário)

Quando questionados se o bairro era violento, alguns moradores afirmaram:

Não, tem não [assalto]. Quer dizer, até tem. Mas sempre que tem é quando vem o povo de fora, de Paulo Afonso, esses lugares assim. Eles veem o nome 'bom sossego' aí vem pra cá porque sabem que é sossegado [risos]. Mas o povo daqui mesmo, não tem isso não. É tranquilo (Fala do morador 1 - extraída do diário).

Gosto de morar aqui, pois é um bairro bem tranquilo com relação a violência, porém ainda falta muita coisa no bairro (Fala do comerciante 1 - extraída do diário).

A violência que a gente fala muito, é quem vem de fora né [...] e quando vai crescendo, vai chegando gente de fora, aí quando chega gente de fora que quer tomar posse, aí as pessoas não aceitam né que cheguem querendo mandar, mas a questão da violência é praticamente um índice muito baixo, quase zero (Fala do representante da associação do bairro - extraída do diário).

Com relação às notícias jornalísticas sobre os principais problemas do bairro e da cidade, foi possível identificar algumas situações que confirmam ou contradizem os relatos de alguns moradores e comerciantes locais, em especial no que diz respeito à questão da saúde e segurança. A seguir, apresentam-se alguns títulos de manchetes extraídas de blogs e sites da região, divulgadas nos últimos quatro anos: "Praças do Bairro Bom Sossego estão abandonadas"; "Bandidos invadem estabelecimento para roubar cofre em Delmiro Gouveia"; "Homem suspeito de agredir e ameaçar a esposa é preso armado com faca em Delmiro Gouveia"; "Gestão de Delmiro Gouveia recebeu 35 milhões em dois anos, e mesmo assim Saúde enfrenta muitos problemas"; "Roubo aconteceu na tarde do último sábado, no Bairro Bom Sossego. Após o assalto, criminosos fugiram com destino ao centro da cidade".

Para as licenciandas esse momento de conhecimento da comunidade local foi muito importante, uma vez que:

[...] a gente foi ali observar e estudar a realidade mesmo e não foi criada somente a partir da nossa observação, foi a partir do que as pessoas que moram ali, que convivem com aquela realidade, tinham para nos mostrar para nos dizer o que ela sente em relação a todos os fatos que aconteceram ali naquela localidade (Grupo Focal - Nísia - grifo nosso). 
[...] a gente ouviu os moradores de várias formas, moradores que são comerciantes, pessoas que moram ali, mas precisam trabalhar fora, representantes [...], representantes das igrejas e de algo assim, a gente não limitou a um grupo específico de pessoas, por exemplo [apenas] as mães e os pais responsáveis das crianças que estudam na escola (Grupo Focal - Jaqueline).

As licenciandas atribuíram importância a esse momento da Investigação Temática pelo fato delas terem se sentido ativas não somente no processo de observação dos problemas locais, mas também por exercitar a escuta do Outro, buscando compreender o que o povo pensava e sentia sobre os fatos e problemas vivenciados. Tais falas evidenciam o que podemos chamar de despertar do educador para as condições de vida da comunidade escolar. Isto é, o processo de imersão proporcionado pelas etapas de investigação revela cenários antes despercebidos em um planejamento que, realizado à revelia da comunidade, silencia dimensões importantes do processo educativo. $\mathrm{O}$ primeiro desvelamento que se percebe na Investigação Temática é, portanto, aquele vivenciado pelos próprios educadores/as ao reconhecerem as condições materiais de vida dos/as educandos/as. Pernambuco (1993), ao explicitar os conflitos vivenciados por um grupo de educadores/as ao se aproximarem da comunidade local, sinaliza que esse processo envolve o "pensar sobre o pensar" dos professores/as, uma análise da realidade que transcenda o senso comum, proporcionando o distanciamento necessário para a identificação das contradições existentes.

No mesmo sentido, a fala de uma licencianda que estava atuando na escola na condição de aluna vinculada ao PIBID, evidencia como a pesquisa realizada a partir do processo de Investigação Temática amplia o conhecimento do/a professor/a sobre os problemas vivenciados pela população local.

E outro aspecto [importante] foi que eu já estava atuando na escola que está situada no bairro que a gente realizou esse trabalho e nunca a gente tinha feito isso. Já tinha meses lá e a partir desse trabalho que eu né, falando particularmente, conheci ainda mais a realidade dos meus alunos que estão inseridos naquele bairro, porque antes não sabia disso, só o que a gente vê superficialmente quando está naquela região, mas quando a gente vai investigar mesmo, vai ouvir as pessoas, aparece muito mais coisas para além do que está visível (Grupo Focal Jaqueline).

Essa fala da licencianda parece revelar que esse conhecimento da realidade dos/as alunos/as a partir da Investigação Temática possibilitou ampliar seu olhar sobre aquela escola e, consequentemente, potencializou a sua formação vivenciada no âmbito do programa de iniciação à docência. Essa fala vai ao encontro também de uma preocupação de Brick (2017) sobre os perigos de realizar o processo de Investigação Temática desconsiderando o diálogo autêntico como eixo central na busca dos Temas Geradores. Segundo o autor, deixar de considerar o pensar dos sujeitos (que, por vezes, estão envolvidos em contradições que se manifestam em distintas interpretações da 
realidade compartilhada pela comunidade) recai no fato de negá-los à sua condição de sujeitos do conhecimento e de transformação das situações que lhes envolvem.

Assim sendo, a equipe de pesquisadores poderia cair numa postura assistencialista e pautar sua prática educativa numa perspectiva antidialógica, em que os/as educadores/ as não dialogam com a comunidade e seus educandos/as, mas costumam dissertar sobre o objeto de conhecimento para eles (Brick, 2017). As licenciandas participantes do processo aqui descrito, já na primeira etapa que envolveu o conhecimento da comunidade, explicitaram indicativos que evidenciam terem compreendido a importância da sua participação ativa durante o processo de ouvir o Outro, ou seja, reconhecendo o diálogo como fundamental na prática educativa freireana, a exemplo do que explica Nísia:

Então, para mim é um dos trabalhos que eu mais me lembro justamente por ter sido um processo mais [...] por eu me sentir mais ativa na construção desses planos de aula. Não foi algo que surgiu de um conteúdo, foi de uma realidade que a gente buscou analisar e foi ver de perto a opinião de cada um dos moradores (Grupo Focal - Nísia - grifo nosso).

Na referida fala, bem como em outras, também sobressai o protagonismo docente experienciado mediante o processo de Investigação Temática. A concepção freireana de educação tece críticas ao papel secundário atribuído ao/a professor/a no processo de construção curricular na educação bancária, no qual cabe a ele executar currículos concebidos por outros (Auler \& Delizoicov, 2015). A busca por Temas Geradores atribui ao/a professor/a um novo papel em que, mediante o diálogo com a comunidade escolar, desempenha uma ação crítica e criativa na concepção de programas escolares, afirmando a sua vocação ontológica do Ser Mais (Freire, 1987). Tal dimensão, sinalizada pelas licenciandas, também tem sido evidenciada em outros trabalhos desenvolvidos no contexto da formação inicial de professores/as fundamentados na concepção educacional de Paulo Freire, a exemplo daqueles analisados por Hunsche e Auler (2012), Roso et al. (2015) e Ferreira et al. (2019).

O que se observou nesta primeira etapa da Investigação Temática, que teve como foco a construção de um dossiê da comunidade, foi o envolvimento das licenciandas na busca por informações sobre os sujeitos que ali viviam. O contato direto com a comunidade, o "ir a campo", "ver de perto a opinião de cada um dos moradores" e "conversar com as pessoas", de fato, foram os aspectos que mais marcaram as licenciandas nessa etapa, especialmente a licencianda Jaqueline que relatou já atuar na escola dessa comunidade (enquanto bolsista do PIBID), sem ao menos conhecer o contexto no qual está situada. Assim, ao investigar a comunidade, ela destacou: "[...] quando a gente vai investigar mesmo, vai ouvir as pessoas, aparecem muito mais coisas para além do que está visível". Essa escuta do Outro é o que passa a ampliar a visão de mundo das licenciandas e sinaliza para a centralidade desse processo na obtenção de Temas Geradores. 


\section{ii) Análise das informações e seleção do Tema Gerador}

Nesta etapa, cada equipe de licenciandas ficou responsável por levar para a aula da disciplina de PCA as informações que foram obtidas com a pesquisa sobre a comunidade, tais como: fotografias referentes aos principais problemas do bairro, as notícias extraídas dos sites e blogs da região e as falas dos sujeitos (moradores, comerciantes e lideranças do bairro) registradas nos seus diários. As licenciandas se organizaram em pequenos grupos e analisaram essas informações, que podem ser denominadas como codificações (Freire, 1987), utilizando as etapas da ATD $^{6}$, (Moraes \& Galiazzi, 2011). Esse processo foi orientado pela seleção prévia, por parte da docente da disciplina, de pequenos conjuntos de informações, obtidas durante o primeiro momento da Investigação Temática, para serem analisadas pelos grupos das licenciandas. Assim, cada equipe ficou responsável por fazer a leitura minuciosa dos materiais e grifar os aspectos que mais chamavam a atenção sobre os problemas do bairro - resultando nas unidades de significado da ATD.

$\mathrm{Na}$ etapa da categorização da ATD, cada grupo identificou as situações problemáticas semelhantes entre as unidades de significado, agrupando-as mediante a construção de cartazes com suas equipes. Em seguida, tais informações foram socializadas para toda a turma, resultando nas seguintes categorias: Saúde Precária, Visão Geral do Bairro, Falta de Saneamento Básico, Violência, Falta de infraestrutura, Problemas de Trânsito, Falta de Lazer. Posteriormente, foi construído um novo cartaz coletivo com essas informações, que foram fundamentais para seleção do Tema Gerador, intitulado: "Da realidade às contradições: a falta de consciência do papel social e coletivo dos moradores do bairro Bom Sossego".

Após isso, cada equipe ficou responsável por apresentar em sala de aula suas considerações acerca da análise do Tema Gerador selecionado, constituindo, assim, um metatexto oralizado. Sobre isso, as licenciandas explicaram como ocorreu esse processo de seleção do tema:

Diante da pesquisa feita e de todas as informações coletadas e apuradas, construímos em sala de aula um quadro com todos os problemas que foram

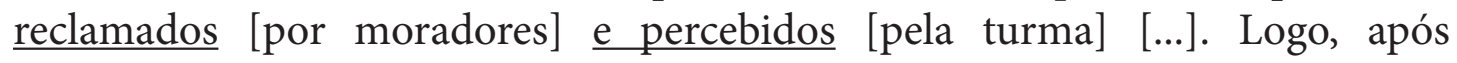
debatermos sobre os problemas, formou-se grupos na sala para que cada um após a discussão, criasse um possível tema gerador, e no final toda turma escolhia apenas um tema que abrangesse os problemas e a realidade local dos moradores (Portfólio - Margareth, grifos nossos).

A escolha [do tema] partiu da visualização das contradições encontradas nas falas dos moradores em relação à qualidade do bairro. [...] O tema pensado abrange também a falta de consciência social e coletiva diante dos problemas que atingem o bairro, ou seja, o pensamento individualista e não crítico. Junto a isso, os moradores tendem a transferir toda a responsabilidade dos problemas presentes no bairro para o poder público (Portfólio - Natália - grifos nossos).

6 A utilização da ATD na Investigação Temática tem sido uma das alternativas metodológicas para a análise das informações do dossiê (ver, por exemplo, Milli, Solino \& Gehlen 2020). 
As falas das licenciandas explicitam a importância que elas atribuíram ao Tema Gerador ser construído com base no pensar do povo sobre as situações concretas que os envolvem. De fato, a compreensão que o povo possui acerca dos problemas que os cercam, por ser gerado historicamente por múltiplas razões, não escapa de ser, também, contraditório. E é nesse sentido que a fala da licencianda vai ao encontro do que Freire (1991) afirma sobre a realidade concreta dos sujeitos que deve ser investigada:

Para muitos, a realidade concreta de uma certa área se reduz a um conjunto de dados materiais ou de fatos cuja existência ou não, de nosso ponto de vista, importa destacar. Para mim, a realidade concreta é algo mais que fatos ou dados tomados mais ou menos em si mesmos. Ela é todos esses fatos e todos esses dados e mais a percepção que deles esteja tendo a população neles envolvida ( $\mathrm{p}$. 35, grifo nosso).

É exatamente essa concepção de Paulo Freire que fundamenta o processo de obtenção de Temas Geradores como objetos cognoscitivos, os quais versam sobre a realidade experimentada pelo povo, que foi identificada pelas licenciandas:

O tema foi escolhido de acordo com a opinião dos moradores entrevistados do bairro, que desconhecem os problemas existentes no local por olhar apenas o espaço onde sua casa está inserida e não ver os problemas existentes em outras ruas e a visão desses entrevistados contradiz com a realidade que foi apurada no decorrer da pesquisa (Portfólio - Margareth - grifo nosso).

[...] a gente foi perguntar às pessoas que trabalham lá e teve perguntas e respostas positivas e tudo mais e de acordo com as outras respostas dos moradores que a gente teve acesso, a gente percebeu divergências, né? E foi de acordo com isso que a gente pode construir o tema gerador que foi de total relevância, porque houve contradições entre as falas deles (Grupo Focal - Ester - grifo nosso).

Foi utilizado, portanto, como principal critério pelas licenciandas para a identificação do Tema Gerador a presença de contradições nas falas dos moradores, seja entre essas falas ou entre a sua percepção e os dados materiais coletados com a pesquisa de campo. Essa interpretação das licenciandas está de acordo com a natureza conflituosa desses temas. A esse respeito, Silva (2004) chama atenção para o fato de que os Temas Geradores, mais do que temáticas motivacionais ou recursos didáticos utilizados para atrair o interesse dos estudantes, constituem objetos de estudo selecionados mediante investigação junto à comunidade "[...] a partir de seu caráter significativo, conflituoso e contraditório. São limites que a comunidade possui de intervir concretamente em situações de desumanização por ela vivenciada" (p. 182 e 183). Segundo o autor, tais temas proporcionam a mediação crítica e tensa entre as representações de realidade de educandos/as e educadores/as, revelando contradições entre as concepções de realidade dos diferentes agentes da comunidade escolar, representadas nas falas significativas (Silva, 2004). 
Sobre a presença de contradições na pesquisa realizada, a discente Margareth tenta refletir sobre a postura dos moradores frente às situações vivenciadas:

[...] a gente estudou em sala de aula textos que falam sobre isso sobre a realidade local e quando a gente foi fazer a pesquisa [...] a gente sentiu que os moradores, a maioria que a gente entrevistou, eram bem acomodados, a gente pergunta algumas coisas e para eles tudo era perfeito. Para eles tudo no bairro era perfeito e depois que a gente foi fazer as pesquisas a gente viu muitas coisas que na verdade não eram como eles falaram, né? Então a gente sentiu isso também, essa comodidade dos moradores do bairro que a gente fez a pesquisa (Grupo Focal Margareth - grifos nossos).

Ao se referir à comodidade dos moradores locais, a licencianda Margareth evidenciou sua preocupação com as razões que os levaram a se acomodarem ou se silenciarem diante dos problemas que vivenciam. Aqui é importante destacar que o comodismo e o silenciamento, muitas vezes, é fruto de uma construção histórica, ou seja, da existência de situações-limite que impedem o ser humano de Ser Mais, de vislumbrar outras possibilidades. Vale frisar que o conceito de falas significativas, explorado na presente pesquisa, está fundamentado nessa ideia de "situações-limite" desenvolvida por Freire (1987). Essas falas, ao resgatarem os conflitos presentes nas vozes da comunidade, expressam circunstâncias que impedem a percepção histórica da realidade concreta, das relações entre seres humanos e a construção do real. Por essa razão, identificamos aqui a necessidade de se problematizar essa percepção das licenciandas acerca da passividade dos moradores diante das situações-problema vivenciadas, para que essas possam ser compreendidas e problematizadas junto aos alunos/as no contexto da sala de aula.

Outro aspecto a sinalizar na análise que as licenciandas fizeram, sobre as falas da comunidade local, diz respeito à transferência de responsabilidade entre os moradores e o poder público, como aponta Natália:

[...] Então há necessidade de pagar para se sentir seguro, então assim trabalhar também a questão da culpa é que a gente percebia que os moradores tendiam a jogar a culpa no poder público e provavelmente se procurasse o poder público eles iriam botar a culpa também na população, sabe. Então acho que era papel do morador enquanto sujeito social (Grupo Focal — Natália).

A culpa que a licencianda Natália ressalta refere-se ao papel/responsabilidade que cada sujeito tem frente ao processo histórico de existência e perpetuação do problema investigado. Afinal, as visões limítrofes das condições materiais de vida da comunidade local e escolar também podem estar associadas aos condicionamentos ideológicos aos quais os sujeitos estiveram submetidos em sua experiência da "cultura do silêncio" (Freire, 1981). Uma compreensão mais ampla acerca da acomodação dos moradores locais apresentada pelas licenciandas poderia ter sido favorecida mediante a construção de uma Rede Temática, tal como proposto por Silva (2004). 
A Rede Temática constitui uma representação relacional sintética e concreta das diferentes concepções dos sujeitos envolvidos na construção da prática educativa, orientando o desvelamento das contradições sociais nas dimensões micro e macro da organização social, cultural e econômica da realidade (Silva, 2004). A construção da rede proporciona o distanciamento, a re-leitura coletiva da realidade que a constitui como um referencial pedagógico a partir do qual será estruturado o programa escolar (Silva, 2004). Assim, em sua construção, a análise das informações obtidas na pesquisa sociocultural com a comunidade é aprofundada, proporcionando uma compreensão mais ampla das contradições sociais que possibilita identificar seus nós problemáticos que guiarão o diálogo em sala de aula.

Chama-se a atenção para a forma com que as licenciandas analisaram os modos com que os sujeitos da comunidade fazem uma leitura sobre a realidade em que vivem. Para tanto, as licenciandas estruturaram parâmetros para interpretar esses modos de pensar da comunidade. Ainda que não tivessem tido como referência os critérios de seleção de falas significativas, tal como apresentado por Silva (2004), elas utilizaram aspectos relacionados às situações-limite como critérios para selecionar essas falas, pautados, por exemplo, em: falas contraditórias, pensamento individualista, comodismo e transferência de responsabilidade. No estudo de Jesus et al. (2021), os licenciandos do PIBID também criaram seus critérios para selecionarem as falas significativas e organizam as respostas a partir de situações significativas e contraditórias, o que foi fundamental para a investigação do tema.

O que se destaca na etapa da seleção do Tema Gerador discutida na presente categoria é que as licenciandas compreenderam que a identificação do tema não se dá de forma aleatória, tampouco espontânea, mas a partir de um processo dialógico de pesquisa e escuta do/com o Outro. Isso indica que a compressão das licenciandas está atrelada à análise detalhada das falas da comunidade local. Então, para além de ouvir o Outro, a análise da sua fala, seguindo um conjunto de parâmetros, foi condição necessária para as licenciandas entenderem que os Temas Geradores emergem da dinâmica investigativa da realidade concreta da comunidade local, a qual se realiza por meio da análise dos problemas e da percepção que deles esteja tendo o povo (Freire, 1991). Não basta ter um conjunto de falas e destacar o que mais "aparece" nelas, é preciso ter uma escuta sensível e um olhar crítico sobre elas, pautados naquilo que Silva (2004) caracteriza de falas significativas.

\section{iii) Seleção dos conteúdos programáticos e elaboração de planos de aulas de Ciências}

Após a análise das problemáticas locais e seleção do Tema Gerador, cada equipe de licenciandas ficou responsável por discutir quais conteúdos e conceitos científicos poderiam ser selecionados a partir do tema. Cabe ressaltar que no âmbito dos cursos de Pedagogia, as professoras são formadas para trabalharem com diferentes disciplinas escolares, o que requer um conhecimento geral de várias áreas para ensinar crianças do 
Ensino Fundamental - Anos Iniciais. Esse aspecto da formação inicial no âmbito da pedagogia contribuiu com o olhar interdisciplinar, que é importante para a seleção dos conteúdos e conceitos necessários para compreensão dos temas. Contudo, neste artigo foi realizado um recorte para apresentar e analisar somente o processo de seleção dos conteúdos e elaboração de planos de aulas de Ciências, conforme é possível observar na Figura 2.

Figura 2. Seleção dos conteúdos escolares de ciências realizada pelas licenciandas

Tema Gerador: Da realidade às contradições: a falta de consciência do papel social e coletivo dos moradores do bairro Bom Sossego

\begin{tabular}{|l|l|}
\hline Disciplina & Conteúdos \\
\hline Ciências Naturais & Lixo \\
& Substâncias tóxicas do lixo \\
Doenças causadas pelo lixo \\
Rio São Francisco como fonte de água para a cidade \\
Preservação do Meio Ambiente \\
Higiene \\
Saneamento Básico \\
Estação de Tratamento de Água e Esgoto \\
Consequências da poluição ambiental
\end{tabular}

Fonte: Elaborado pelo/as autor/as

A seleção desses conteúdos e conceitos científicos não teve como suporte a construção de uma Rede Temática e a proposição de um Contratema, tal como proposto na sistematização das etapas da Investigação Temática por Silva (2004). Ou seja, a programação foi construída tendo como referências apenas as situações-problema identificadas pelas licenciandas e contidas no Tema Gerador selecionado, a partir do qual foi realizada a discussão dos conhecimentos necessários para uma compreensão mais crítica a seu respeito.

Sob o ponto de vista da análise das compreensões das licenciandas sobre o processo de Investigação Temática para construção de planejamentos curriculares significativos, ficou claro, para elas, a necessidade de considerar situações significativas que representam a compreensão dos sujeitos sobre sua realidade local para a elaboração das atividades de Ciências Naturais, conforme é possível observar nas falas a seguir:

[...] no nosso caso o plano de Ciências foi [construído] justamente para buscar uma conscientização mesmo da população e, como era o plano de aula, seria pra ser posto [trabalhado] em uma escola, o objetivo seria esse mesmo [...]: para conscientizar mesmo e as pessoas terem mais conhecimento do que estava presente ali (Grupo Focal - Ester).

[...] no nosso grupo a gente não escolheu pela disciplina Ciências, a gente escolheu 
[...] o lixo, e aí o fato do lixo o conteúdo se enquadrar em Ciências. Então foi basicamente [...] que a gente buscou pensar na qualidade de vida daqueles alunos, dos professores, dos moradores. Pensar como Ester falou da conscientização social (Grupo Focal - Jaqueline).

As licenciandas também evidenciaram que a escolha dos conteúdos e conceitos de Ciências foi realizada de modo a atender os problemas e os modos limítrofes com que os sujeitos da população compreendiam os problemas locais. Dessa forma, constatou-se uma preocupação de que as aulas de Ciências sejam direcionadas pelo Tema Gerador, com o intuito de conscientizar os/as educandos/as acerca dos problemas identificados. Assim, o critério de seleção dos conteúdos, utilizado pelas licenciadas, estava alinhado com o objetivo das aulas de Ciências na perspectiva freireana: a conscientização dos/as educandos/as.

Dessa forma, ao tratarem da construção do programa escolar, mais uma vez é possível perceber a postura dialógica das licenciandas ao considerarem os/as educandos/ as como sujeitos do conhecimento (Delizoicov et al., 2011), ao pensarem neles como indivíduos demarcados pelos determinantes sociais que condicionam suas formas de compreender os problemas locais. Ao invés de planejarem aulas com o propósito de informar aos educandos/as os limites de sua compreensão sobre a realidade, as discentes propuseram aulas que aliam o conhecimento do povo e os conhecimentos científicos (o que inclui os conceitos das Ciências Naturais) como um modo de problematizar o pensar desses sujeitos com o propósito de ampliar suas compreensões e intervenções no mundo. Isto pode ser observado nas considerações da licencianda Natália a respeito do planejamento das aulas de Ciências:

[...] na hora de pensar nesses conteúdos, pensei neles não apenas como aspectos a serem estudados em sala, mas sim como um momento de analisar o pertencimento do aluno no bairro, o reconhecimento do seu papel social, enquanto morador, $\mathrm{e}$ sua criticidade diante dos problemas presentes naquele lugar que ele faz parte, em seu bairro (Portfólio - Natália - grifo nosso).

Desse modo, a seleção dos conteúdos não ocorreu mediante uma listagem concebida por outros e meramente executada pelos/as professores/as nas escolas, a sua escolha foi realizada pelas futuras educadoras de modo a contemplar as necessidades dos/as educandos/as de ampliar os seus modos de compreender sua realidade local. Daí a importância do exercício analítico de escuta proporcionado pela Investigação Temática e que constitui não só o fundamento para a elaboração do planejamento escolar, mas também o fio condutor da implementação do programa em sala de aula. Durante a seleção do conteúdo programático e a elaboração dos planos de aula foi possível identificar que as licenciandas estão alinhadas com as ideias freireanas de educação, uma vez que tiveram como referência as contradições presentes nas falas dos moradores como aspectos necessários para efetivar o diálogo autêntico em sala de aula. Deste modo, os conteúdos científicos passam a ser vistos como conhecimentos importantes 
que auxiliam os/as educandos/as na tomada de consciência das situações problemáticas vivenciadas. É neste sentido que as licenciandas selecionaram os conteúdos com vistas à proposição de um ensino de ciências voltado à conscientização dos/as educandos/as.

Algo que me remete muito às ideias de Freire é o fato de a gente planejar [...] e não só usar essa realidade como instrumento para planejar as nossas aulas, mas também é fazer com que a educação seja um instrumento de transformação dessa mesma realidade. Então, ao mesmo tempo que a gente pega essa realidade para ter como instrumento nas nossas aulas, as nossas aulas, também, para os alunos ali vão servir como conscientização e instrumento para que eles possam fazer transformação ali (Grupo Focal — Nísia).

Mais uma vez é possível observar a convergência da fala dessa licencianda Nísia com os pressupostos da educação dialógica e problematizadora de Freire (1987), pois: “é na realidade mediatizadora, na consciência que dela tenhamos, educadores e povo, que iremos buscar o conteúdo programático da educação. O momento deste buscar é o que inaugura o diálogo da educação como prática da liberdade" (p. 50). Aqui tem-se, portanto, um dos aspectos centrais da perspectiva educacional freireana, a dimensão do diálogo que se estabelece desde o planejamento do programa escolar. Diálogo esse que, coerente com uma concepção ético-crítica, coloca como ponto de partida do processo educativo a escuta do Outro, essencial para uma educação que se faça libertadora, comprometida com a superação das situações de desumanização dos sujeitos da comunidade escolar. Afinal, como nos fala Silva (2004), qual o sentido de abordar tópicos como ciclo da água, sistemas orgânicos do corpo sem antes perguntar aos educandos/as se em suas casas há água encanada? Como propor, por exemplo, hábitos de higiene se em sua comunidade não há água potável? Quais os propósitos de um currículo que silencia as dimensões concretas da vida desse Outro?

Os conteúdos de Ciências Naturais, portanto, serviriam ao processo de conscientização dos/as educandos/as das escolas, o que não se efetiva se a sua escolha ocorrer de modo apartado da realidade que os sujeitos vivenciam. Realidade que, importa novamente destacar, não se resume aos fatos/problemas observados pela equipe de pesquisadores, mas "a percepção que deles esteja tendo a população neles envolvida” (Freire, 1991, p. 35). É possível constatar tal preocupação das licenciandas ao estruturarem os planos de aulas de Ciências para o Ensino Fundamental - Anos Iniciais, tendo como referência os Três Momentos Pedagógicos (Delizoicov et al., 2007), as quais apresentaram diferentes problematizações para iniciar a aula:

Você considera seu bairro limpo? No seu bairro tem lixos nas ruas? Quais os problemas que o lixo causa? O que você faz para manter seu bairro limpo? No seu bairro tem coleta de lixo? Quantas vezes por semana? Você sabe o que é Coleta Seletiva? Seu bairro tem? (Portfólio - Plano de Aula — Natália). 
Alguém já ouviu falar sobre saneamento básico? Sabem o que é isso? E o que significa qualidade de vida? Qual a relação entre esses dois termos? Qual a visão que vocês têm de um ambiente com e sem saneamento básico? Na concepção de vocês, o bairro x tem saneamento básico? (Portfólio - Plano de Aula - Ester).

Essas problematizações apresentadas pelas licenciandas em seus planos de aulas parecem, em alguma medida, terem como ponto de partida situações relacionadas às falas significativas da comunidade e, em outros momentos, aspectos que se aproximam mais da dimensão conceitual. Por exemplo, a questão "Você sabe o que é Coleta Seletiva?", está mais próxima da busca de concepções sobre o conceito "coleta seletiva" do que da compreensão que os/as alunos/as podem ter sobre elementos que estão presentes em sua realidade. Isso pode ser justificado pelo fato de que na disciplina de PCA não foi possível trabalhar de maneira aprofundada a noção de problematização presente nos $3 \mathrm{MP}$, uma vez que a carga horária geral da disciplina era de 80 (oitenta) horas e essa etapa da elaboração dos planos de aulas ficou para o final do semestre. Isso, de certa forma, acabou fragilizando as compreensões das licenciandas sobre como organizar perguntas problematizadoras no contexto da pedagogia freireana, as quais necessitam ter como ponto de partida as falas significativas (Silva, 2004).

Essa limitação na elaboração de perguntas problematizadoras pode ser identificada de modo explícito no plano desenvolvido pela equipe de Nísia: "Vocês sabem o que é lixo? Vocês sabem o que é reciclar? Vocês sabem o que é meio ambiente? Vocês sabem que há lixos que podem ser reciclados? Vocês sabem para onde vai o lixo que produzimos?" (Portfólio - Plano de Aula - Nísia).

Compreende-se que a elaboração da Rede Temática, proposta por Silva (2004), poderia ter contribuído tanto com o desenvolvimento de uma compreensão mais ampla da noção de problematização quanto com a problematização dos traços da educação bancária arraigados historicamente em nossas experiências educativas, do opressor introjetado em nós (Freire, 1987), que dificultam a compreensão de uma lógica de planejamento com outro referente. Tal rede, ao proporcionar uma análise relacional das contradições sociais e cotejar a visão de educandos/as e educadores/as a respeito do Tema Gerador, possibilitaria uma análise mais pormenorizada das informações identificadas e a demarcação do ponto de partida (Tema Gerador) e do ponto de chegada (Contratema) da proposta elaborada.

Por outro lado, destaca-se que essa dificuldade vivenciada pelas licenciandas pode ser localizada mesmo em produções da área de Educação em Ciências, na qual, segundo Araújo et al. (2013), muitos trabalhos utilizam a problematização a partir de uma abordagem conceitual e de perguntas, distanciando-se da proposta original dos Momentos Pedagógicos. Contudo, esses autores também destacam que "mesmo que os momentos pedagógicos sejam trabalhados a partir de uma abordagem conceitual, torna-se válida sua implementação, pois rompe com o ensino tradicional, onde apenas se depositam conteúdos" (p. 192). Com isso, há indicativos de que um trabalho pautado na dialogicidade e problematização requer maiores aprofundamentos que 
possibilitem tanto o trabalho a partir de temas, que favorecem a elaboração de perguntas problematizadoras (Araújo et al., 2013), quanto a problematização dos traços da educação bancária presentes em nossa prática pedagógica.

Nesse contexto, apesar das licenciandas não conseguirem elaborar de maneira mais crítica esse primeiro momento pedagógico - problematização - nos planos de aulas, ainda assim, parece ter ficado claro para elas a importância de considerar a realidade dos/as alunos/as durante o planejamento. Este aspecto foi apontado pela licencianda Nísia como um significativo redirecionamento da lógica curricular vigente nas escolas.

Elaborar planos de aula, portanto, deixou de ser apenas uma seleção e organização dos conteúdos que se adequam, em maior ou menor grau, à realidade dos alunos aos quais o planejamento se destina, e passou a seguir o 'caminho' oposto. Mudar a rota dos fatos no momento de planejar faz toda diferença na aprendizagem dos alunos, visto que para que eles aprendam de forma significativa e prazerosa, os conhecimentos [...] devem estar em constante diálogo com a realidade concreta dos mesmos (Portfólio - Nísia).

Assim sendo, pôde-se concluir que o diálogo autêntico, o qual considera o Outro como sujeito de conhecimento, que possui suas compreensões acerca da realidade demarcada por condicionantes histórico-culturais que permeiam a vivência daquela comunidade, foi considerado pela licencianda Nísia como aspecto fundamental para que a seleção dos conteúdos e a elaboração das aulas de Ciências Naturais sejam realizadas seguindo um "caminho oposto" ao que comumente se realiza nas instituições escolares. Esse aspecto é um pressuposto teórico que norteia práticas educativas pautadas na ATF (Delizoicov et al., 2011), uma vez que o diálogo autêntico como fundamento da prática educativa libertadora se inaugura na busca do conteúdo programático. Nas palavras de Freire (1987), "o momento deste buscar é o que inaugura o diálogo da educação como prática da liberdade. É o momento em que se realiza a investigação do que chamamos de universo temático do povo ou o conjunto de seus temas geradores" (p. 50).

Nessa categoria, destacaram-se evidências de algumas dimensões essenciais do planejamento didático-pedagógico na perspectiva freireana. Especificamente, as licenciandas apresentaram reflexões sobre a noção de conteúdo escolar relacionadas tanto aos critérios empregados na sua seleção quanto ao papel que desempenham no processo educativo. Foi identificada por elas uma outra lógica de planejamento curricular, pautada por princípios ético-críticos. Contudo, também foi constatada a necessidade de maiores discussões a esse respeito, no sentido de possibilitar problematizar práticas alinhadas à educação bancária internalizadas pelas licenciandas ao longo da sua trajetória escolar, o que sinaliza para a importância de uma abordagem sistemática dos pressupostos educacionais que balizam a ATF, em diferentes momentos da formação inicial dos/as professores/as. Isto é, para além da disciplina de PCA, contemplando, também atividades a serem realizadas em outras disciplinas do curso de Pedagogia. 


\section{Algumas contribuições para a Educação em Ciências no curso de Pedagogia}

Os resultados do estudo apontam que o desenvolvimento de elementos da Investigação Temática na formação inicial, a exemplo do que foi realizado no curso de Pedagogia da Universidade Federal de Alagoas, Campus do Sertão, contribuiu para que as licenciandas compreendessem que a escuta do Outro constitui um diferencial da perspectiva ATF em todos os momentos da Investigação Temática realizada.

No que se refere ao momento em que as discentes desenvolveram a pesquisa sociocultural Conhecendo a comunidade local, foi evidenciado o protagonismo das futuras educadoras durante o planejamento de propostas educativas mediante as etapas da Investigação Temática, sob a atuação crítico-analítica, criativa e propositiva. Além disso, esse momento contribuiu com a construção de um outro referente para a organização curricular, uma vez que as licenciandas destacaram a importância desse processo de escuta do Outro, de considerar as condições materiais de vida da comunidade escolar e local e a percepção que delas tenham os sujeitos no processo de ensino-aprendizagem.

$\mathrm{Na}$ etapa de Análise das informações e seleção do Tema Gerador, as licenciandas aprofundaram suas compreensões a respeito do Tema Gerador, seu diferencial em relação a outras situações/temáticas comumente abordadas em sala de aula, apresentando indicativos de que desenvolveram uma escuta sensível e crítica das falas da comunidade local. Além disso, ao realizarem a Seleção dos conteúdos programáticos e elaboração dos planos de aula ficou claro o intuito das licenciandas de orientarem as aulas de ciências de tal forma que os conteúdos escolares sirvam como instrumentos para que os/as educandos/as compreendam melhor sua realidade e nela possam intervir. Isto ficou evidente ao observar a sintonia entre o critério de seleção dos conteúdos que as licenciandas utilizaram e o objetivo das aulas de ciências planejadas por elas. Daí que foi possível concluir que as licenciandas compreenderam que a escuta do Outro constitui um pressuposto fundamental para o quefazer educativo numa perspectiva freireana.

Destaca-se que a escuta do Outro tem na análise das falas dos sujeitos o ponto central para a identificação de Temas Geradores. São as falas que revelam as compreensões que os sujeitos estão tendo sobre a realidade que vivem. Embora as licenciandas tenham utilizado diferentes parâmetros para analisar essas falas, ainda é preciso avançar nesse aspecto e, com isso, há necessidade de se investigar outros instrumentos que possam contribuir nessa análise, para além do conjunto de parâmetros apresentados por Silva (2004), a exemplo do Instrumento Dialético Analítico (IDA) (Silva \& Gehlen, 2021).

Com isto, enfatiza-se a importância dos estudos, pautados na abordagem de Temas Geradores, explicitarem os parâmetros utilizados no processo de análise das falas dos sujeitos, para que se possa compreender como a equipe de pesquisadores realiza a escuta sensível do Outro nas etapas da Investigação Temática. Isto porque é na escuta do Outro - dos sujeitos da comunidade local e escolar - que emergem as potencialidades da Rede Temática (Silva, 2004; Demartini \& Silva, 2013; Milli et al., 2018) no processo de elaboração de programas curriculares. Assim sendo, a falta de parâmetros para realizar a 
escuta do Outro, isto é, para analisar as falas e identificar quais são aquelas significativas, revela-se como aspecto que necessita de mais atenção em pesquisas que envolvem o trabalho educativo pautado em Temas Geradores.

No contexto desse estudo, este aspecto reverberou na elaboração de planos de aulas de Ciências Naturais, uma vez que foram evidenciadas dificuldades das licenciandas para construir perguntas problematizadoras a partir das falas significativas dos sujeitos da comunidade. Isto porque, de acordo com os 3MP (Silva, 2004), as perguntas a serem elaboradas no primeiro momento pedagógico necessitam estar referidas aos limites de compreensão que os sujeitos da comunidade possuem acerca dos problemas vivenciados. Contudo, as perguntas elaboradas pelas licenciandas estavam mais próximas de um viés conceitual, em que os conceitos são tidos como pontos de partida para iniciar as aulas, revelando a dificuldade de romper com os resquícios da educação bancária que fundamentam a lógica da perspectiva curricular da Abordagem Conceitual (Delizoicov et al., Angotti \& Pernambuco, 2011). Tal Abordagem Conceitual nega a vocação ontológica dos/as educandos/as como sujeitos de conhecimento, o que implica na proposição de conteúdos programáticos como doação de saberes daqueles que "sabem" (educadores/ as) para aqueles que "não sabem" (educandos/as) (Freire, 1987).

Diante dessas limitações observadas durante o processo realizado com as licenciandas em pedagogia, sugere-se adotar, como uma possibilidade, a proposta curricular da Investigação Temática como eixo articulador nos cursos de Pedagogia, entendendo-a como uma dinâmica para conhecer, problematizar e analisar criticamente a realidade escolar e local a partir da perspectiva do Outro. A Investigação Temática pode perpassar os diferentes componentes curriculares do curso, potencializando os processos formativos de forma dialógica e problematizadora, em especial no âmbito dos Estágios Supervisionados, dos projetos vinculados ao PIBID e a Residência Pedagógica, cujas parcerias estabelecidas com as escolas e o caráter teórico-prático dessas atividades curriculares possibilitam a proposição de planejamentos didático-pedagógicos alinhados com uma educação humanizadora. Com isso, criam-se oportunidades para exercitar, nas/os licenciandas/os, a escuta sensível, valorizando a perspectiva do Outro como elemento fundamental para construir uma nova identidade docente, capaz de efetivar práticas educativas democráticas e significativas. O que também possibilita firmar um comprometimento ético-crítico da/o futura/o educador/a com uma educação libertadora, contemplando no seu planejamento de Ciências Naturais e demais áreas de conhecimento a práxis dialógico-problematizadora presente nos Temas Geradores, permitindo assim, o desvelamento da realidade pelos/as educandos/as, sujeitos cognoscentes, com vistas à transformação social.

\section{Agradecimentos}

Os autores agradecem ao Conselho Nacional de Desenvolvimento Científico e Tecnológico (CNPq) pelo apoio financeiro. Processo: 423942/2018-2. 


\section{Referências}

Araújo, L. B., Niemeyer, J., \& Muenchen, C. (2013). Uma análise dos trabalhos presentes nos Encontros de Pesquisa em Ensino de Física (EPEF): problematizações ou perguntas? Congreso Internacional sobre Investigación en Didáctica de las Ciencias, 188-193

Auler, N. M. F., Auler, D. (2015). Conhecer e executar currículos currículos: ampliando o processo formativo de educadores(as). N. M. F. Auler, D. Auler (Orgs.). Concepção e execução do currículo no processo formativo de Licenciandos do PIBID (pp. 13-40). CRV.

Auler, D., \& Delizoicov, D. (2015). Investigação de temas CTS no contexto do pensamento latino-americano. Linhas Críticas, 21(45), 275-296. https://doi.org/10.26512/ lc.v21i45.4525

Brick, E. (2017). Realidade e Ensino de Ciências. (Tese de Doutorado, Universidade Federal de Santa Catarina, Florianópolis, Santa Catarina). Repositório Institucional da UFSC. https://repositorio.ufsc.br/xmlui/handle/123456789/182727

Centa, F. G., \& Muenchen, C. (2016). O Despertar para uma cultura de participação no trabalho com um Tema Gerador. Alexandria: Revista de Educação em Ciência e Tecnologia, 9(1), 263-291. https://doi.org/10.5007/1982-5153.2016v9n1p263

Delizoicov, D. (1982). Concepção Problematizadora do Ensino de Ciências na Educação Formal. (Dissertação de Mestrado, Faculdade de Educação da Universidade de São Paulo, São Paulo, São Paulo). Repositório da Produção USP. https://repositorio.usp.br/ item/000711091

Delizoicov, D. (1991). Conhecimento, tensões e transições. (Tese de Doutorado, Faculdade de Educação da Universidade de São Paulo, São Paulo, São Paulo). Repositório Institucional da UFSC. https://repositorio.ufsc.br/xmlui/handle/123456789/75757

Delizoicov, D., Angotti, J. A. \& Pernambuco, M. M. (2011). Ensino de Ciências: Fundamentos e Métodos (5a ed.). Cortez.

Delizoicov, D., Delizoicov, N. C. \& Silva, A. F. G. (2020). Paulo Freire e o ser humano em processo de formação permanente. Revista Retratos da Escola 14(26), 353-369. http:// dx.doi.org/10.22420/rde.v14i29.1155

Demartini, G. R., \& Silva, A. G. (10-14 de novembro, 2013). Abordagem Temática na Sistematização Curricular para o Ensino de Ciências: gravidez na adolescência em uma escola estadual do município de Sorocaba-SP. Atas do IX Encontro Nacional de Pesquisa em Educação em Ciências, Águas de Lindóia, São Paulo.

Ferreira, M. V., Muenchen, C. \& Auler, D. (2019). Desafios e potencialidade em intervenções curriculares na perspectiva da Abordagem Temática. Ensaio: Pesquisa em Educação em Ciências, 21 (e10499). https://doi.org/10.1590/1983-21172019210108

Freire, P. (1981). Ação cultural para a liberdade (5ª ed.). Paz e Terra. 
Freire, P. (1983). Extensão ou Comunicação? (7a ed.). Paz e Terra.

Freire, P. (1987). Pedagogia do Oprimido. (17 a ed.). Paz e Terra.

Freire, P. (1991). Criando métodos de pesquisa alternativa: aprendendo a fazê-la melhor através da ação. In C. R. Brandão (Org.). Pesquisa participante (pp. 34-41). Brasiliense.

Furlan, A. B. S., Ricci, E. C., Gomes, C. G. S., \& Silva, A. F. G. (5-9 de dezembro de 2011). Abordagem Temática no Currículo de Ciências: a perspectiva ético-crítica na concepção de lixo como condição humana. Atas do VIII Encontro Nacional de Pesquisa em Educação em Ciências, Campinas, São Paulo.

Gatti, B. A. (2005). Grupo focal na pesquisa em ciências sociais e humanas. Líber Livro.

Hunsche, S. \& Auler, D. (2012). O professor no processo de construção de currículos: desafios no estágio curricular supervisionado em ensino de física. Revista Electrônica de Enseñanza de las Ciencias, 11(1), 1-20.

Jesus, E. S., Costa, O. L., Oliveira, L. A. \& Torres, J. R. (25-29 de janeiro, 2021). Educação para a diversidade sexual e de gênero via Abordagem Temática Freireana: um relato de experiência do subprojeto biologia PIBID/UFScar Campus Sorocaba. VIII Encontro Nacional de Ensino de Biologia (ENEBIO), Anais [...], Fortaleza, Ceará.

Mendonça, A. R. (2016). A aposta da reorientação curricular via Tema Gerador no Projeto Parnamirim Interdisciplinar. (Dissertação de Mestrado, Universidade Federal do Rio Grande do Norte, Natal, Rio Grande do Norte). Repositório Institucional - UFRN. https://repositorio.ufrn.br/handle/123456789/24564

Milli, J. C. L., Almeida, E. S. \& Gehlen, S. T. (2018). A Rede Temática e o ciclo temático na busca pela cultura de participação na educação CTS. Alexandria: Revista de Educação em Ciência e Tecnologia, 11(1), 71-100. https://doi.org/10.5007/1982-5153.2018v11n1p71

Milli, J. C. L., Solino, A. P., \& Gehlen, S. T. (2018). A Análise Textual Discursiva na investigação do Tema Gerador: por onde e como começar? Investigações em Ensino de Ciências, 23(1), 200-229. http://dx.doi.org/10.22600/1518-8795.ienci2018v23n1p200

Milli, J. C. L., Solino, A. P., \& Gehlen, S. T. (2020). A análise textual discursiva como uma bússola praxiológica à perspectiva freireana de educação. Revista Pesquisa Qualitativa, 8 (19), 739-767. https://doi.org/10.33361/RPQ.2020.v.8.n.19.373

Moraes, R., \& Galiazzi, M.C. (2011). Análise Textual Discursiva (2ª ed.). UNIJUÍ.

Moreno, G. S. (2020). Investigação temática freireana e uso de fala significativa no ensino de ciências: formação de professores licenciados em Educação do Campo. Revista Brasileira de Educação do Campo, 5(e6432), 1-14. https://doi.org/10.20873/uft. rbec.e6432

Muenchen. C., Magoga, T. F., Schneider, T. M. \& Araújo, L. B. (2019). Os Três Momentos Pedagógicos na formação inicial de professores: o trabalho com Temas Geradores. In G. Watanabe (Org.). Educação Científica Freireana na escola (1ª ed., pp. 73-89). Livraria da Física. 
Ovigli, D. F. B., \& Bertucci, M. C. S. (2019). A formação para o ensino de ciências naturais nos currículos de pedagogia das instituições públicas de ensino superior paulistas. Ciências \& Cognição, 14(2), 194-209.

Paniz, C. M. (2017). O PIBID como política articuladora na construção de currículos críticos: trabalho desenvolvido no Instituto Federal Farroupilha. (Tese de Doutorado, Universidade Federal de Santa Maria, Santa Maria, Rio Grande do Sul). Repositório Digital da UFSM. http://repositorio.ufsm.br/handle/1/13735

Pernambuco, M. M. C. (1993). Significações e realidade: conhecimento. In N. Pontuschka (Org.). Ousadia no diálogo: Interdisciplinaridade na escola pública (1 $1^{\text {a }}$ ed., pp. 67-92). Edições Loyola.

Pires, E. A. C., \& Malacarne, V. (2018). Formação inicial de professores no curso de pedagogia para o ensino de ciências: representações dos sujeitos envolvidos. Investigações em Ensino de Ciências, 23(1), 56-78. http://dx.doi.org/10.22600/15188795.ienci2018v23n1p56

Roso, C. C. (2017). Transformações na Educação CTS: uma proposta a partir do conceito de Tecnologia Social. (Tese de doutorado, Universidade Federal de Santa Catarina, Florianópolis, Santa Catarina). Repositório Institucional da UFSC. https://repositorio. ufsc.br/handle/123456789/187060

Roso, C. C., Santos, R. A., Rosa, S.E., \& Auler, D. (2015). Currículo temática fundamentado em Freire-CTS: engajamento de professores de Física em formação inicial. Ensaio Pesquisa em Educação em Ciências, 17(2), 372-389. https://doi.org/10.1590/198321172015170205

Santos, J. S. \& Gehlen, S. T. (2021). O instrumento dialético-axiológico na seleção de falas significativas: em busca de uma educação científica ético-crítica. Ensaio: Pesquisa em Educação em Ciências, 23 (e24501). http://dx.doi.org/10.1590/1983-21172021230111

Saul, A. M. (2016). Paulo Freire na atualidade: legado e reinvenção. Revista e-Curriculum, 14(11), 09-34.

Silva, A. F. G. (2004). A construção do currículo na perspectiva popular crítica: das falas significativas às práticas contextualizadas. (Tese de Doutorado, Pontifícia Universidade Católica de São Paulo, São Paulo, São Paulo). Biblioteca Digital. https://tede2.pucsp.br/ handle/handle/22098

Silveira, R. A., Piaia, L. \& Gonçalves, F. P. (2020). A Problematização da Abordagem Temática na formação inicial de professores de Química. Química Nova, 43(10), 1-9. http://dx.doi.org/10.21577/0100-4042.20170614

Solino, A. P. (2013). Abordagem Temática Freireana e o Ensino de Ciências por Investigação: contribuições para o ensino de Ciências/Física nos Anos Iniciais. (Dissertação de Mestrado, Universidade Estadual do Sudoeste da Bahia, Jequié, Bahia). 
Sousa, P., Santos, L. H. S., Silva, Y. A. R., \& Gehlen, S. T. (26-30 de janeiro, 2015). Abordagem Temática Freireana no Ensino de Ciências/Física: uma experiência no estágio supervisionado em Física. XXI Simpósio Nacional de Ensino de Física, Anais [...], Uberlândia, Minas Gerais.

Stuani, G. M. (2016). Abordagem Temática Freireana: uma concepção de formação permanente dos professores de Ciências. (Tese de Doutorado, Universidade Federal de Santa Catarina, Florianópolis, Santa Catarina). Repositório Institucional da UFSC. https://repositorio.ufsc.br/xmlui/handle/123456789/171696

Universidade Federal de Alagoas. (2018). Projeto Político Pedagógico do Curso de Pedagogia. https://ufal.br/estudante/graduacao/projetos-pedagogicos/campus_sertao/ projeto-pedagogico-pedagogia-licenciatura-2018.pdf/view 
Ana Paula Solino

Universidade Federal de Alagoas (UFAL, Campus Sertão) Delmiro Gouveia, Alagoas, Brasil ana.solino@delmiro.ufal.br

Polliane Santos de Sousa

Universidade Federal do Recôncavo Baiano (UFRB, Campus Amargosa) Amargosa, Bahia, Brasil polliane.sds@gmail.com

${ }^{(1)}$ Roger Magalhães da Silva Universidade Estadual de Santa Cruz (UESC) Ilhéus, Bahia, Brasil rmasilva@uesc.br

Simoni Tormöhlen Gehlen

Universidade Estadual de Santa Cruz (UESC) Ilhéus, Bahia, Brasil stgehlen@gmail.com

Editora Responsável

Stefannie Ibraim

Manifestação de Atenção às Boas Práticas Científicas e de Isenção de Interesse

Os autores declaram ter cuidado de aspectos éticos ao longo do desenvolvimento da pesquisa e não ter qualquer interesse concorrente ou relações pessoais que possam ter influenciado o trabalho relatado no texto. 